\title{
Favipiravir and Coronavirus
}

\section{Marcos Aurelio Gomes Da Silva*}

Federal University of Juiz De Fora, Brazil

*Corresponding Author: Marcos Aurelio Gomes Da Silva, Federal University of Juiz De Fora, Brazil.
Received: March 24, 2020

Published: May 07, 2020

(C) All rights are reserved by Marcos Aurelio Gomes Da Silva.
Favipiravir is an antiviral drug that selectively inhibits the RNAdependent RNA polymerase of influenza virus. It is phosphoribosylated by cellular enzymes to its active form, favipiravir-ribofuranosyl-5'-triphosphate (RTP). Favipiravir is active against a broad range of influenza viruses, including $\mathrm{A}(\mathrm{H} 1 \mathrm{~N} 1) \mathrm{pdm} 09, \mathrm{~A}(\mathrm{H} 5 \mathrm{~N} 1)$ and the recently emerged $\mathrm{A}(\mathrm{H} 7 \mathrm{~N} 9)$ avian virus. It also inhibits influenza strains resistant to current antiviral drugs, and shows a synergistic effect in combination with oseltamivir, thereby expanding influenza treatment options. Recently, T-705 has been shown to give $100 \%$ protection against aerosol Ebola virus E718 infection in immune-deficient mice as well as inhibiting Ebola virus infection in cell culture.

It has also proven to be effective in combating coronavirus, patients tested negative for the virus four days after taking the drug. Those infected who did not receive treatment with favipiravir took about 11 days to achieve the same result. In addition, 91\% of patients treated with favipiravir showed significant improvements in lung conditions, compared to $62 \%$ in those who did not receive the same medication. Japanese doctors are currently using Avigan for clinical studies in patients diagnosed with Covid-19 who have mild or moderate symptoms of the disease. The expectation is that the drug will prevent the virus from multiplying in the body.

Favipiravir is a prodrug that is metabolized in its active form, favipiravir-ribofuranosyl-5'-triphosphate (favipiravir-RTP), available in oral and intravenous formulations. Human hypoxanthine guanine phosphoribosyltransferase (HGPRT) is believed to play a key role in this activation process. Favipiravir does not inhibit RNA or DNA synthesis in mammalian cells and is not toxic to them.

A mutation in the influenza A virus PB1 gene that confers resistance to favipiravir. The fitness cost of this mutation, resulting from a decrease in polymerase activity, is compensated for by a mutation in the PA gene that can restore polymerase activity and viral growth, while maintaining favipiravir resistance. We use in vitro analyses and structural modeling to link favipiravir resistance to a molecular change in the RdRP active site that affects nucleotide incorporation. Our findings suggest that a universal mechanism for favipiravir resistance exists. Together, these observations are important for the use of favipiravir as an antiviral drug against influenza virus infections in the present and future.

\section{Assets from publication with us}

- Prompt Acknowledgement after receiving the article

- Thorough Double blinded peer review

- Rapid Publication

- Issue of Publication Certificate

- High visibility of your Published work

Website: $\underline{w w w . a c t a s c i e n t i f i c . c o m / ~}$

Submit Article: www.actascientific.com/submission.php Email us: editor@actascientific.com

Contact us: +919182824667 